\title{
Co-culture of Mouse Two-cell Embryos on Human Endometrial Stromal Cells in Proliferative and Secretory Phases
}

\author{
Co-cultivo de Dos Células Embrionarias de Ratón sobre Células Estromales \\ Endometriales Humanos en Fases Proliferativa y Secretora
}

"Taravat Fakheri; "Anisodowleh Nankali; " Mozafar Khazaei; ${ }^{* *}$ Ali Ghanbari;

${ }_{* * * *}$ Mehrandokht Abedini \& ${ }^{* * * *}$ Hamidreza Saeidiborojeni

FAKHERI, T.; NANKALI, A.; KHAZAEI, M.; GHANBARI, A.; ABEDINI, M. \& SAEIDIBOROJENI, H. Co-culture of mouse two-cell embryos on human endometrial stromal cells in proliferative and Secretory phases. Int. J. Morphol., 30(4):1338-1342, 2012.

SUMMARY: There were no significant differences in the distribution of embryos reaching to 2- cells, 4- cells, morula or blastocysts culturing on human endometrial stromal cells (Secretory or proliferative phases). The percent of morula in stage A (without fragmentation), stage B ( $<25 \%$ fragmentation), stage C (25-50\% fragmentation) and stage D ( $>50 \%$ fragmentation) and did not showed significant differences between two coculture groups. Thus, the phase that the endometrial stromal cells were in thereby did not affect on the quality of embryos.

KEY WORDS: Co-culture; Embryo; Endometrium; Mice; Proliferative phase; Secretory phase.

\section{INTRODUCTION}

Treatment of infertile couples has been progressed by developing in vitro fertilization (IVF) that preimplantation embryos are routinely transferred into the uterus.

The concept of improved human preimplantation development and implantation ability by co-culturing embryos in the presence of another cell type (feeder cells) has led to the development of the co-culture system (Beydoun et al., 2010; Teklenburg \& Macklon, 2009).

Multiple cell types have been used for this purpose, ranging from human reproductive tissues, such as oviducts (Bongso et al., 1994; Yeung et al., 1992), endometrium (Jayot et al., 1995), oviduct-endometrial sequential co culture (Bongso et al., 1994), and cumulus-granulosa cells (Freeman et al., 1995; Saito et al., 1994), to nonhuman cells (Wiemer et al., 1993) or nonhuman cell lines (Menezo et al., 1990; Schillaci et al., 1994) and even cells from ovarian carcinoma (Ben-Chetrit et al., 1996). Unfortunately, there is no general agreement on the efficacy of different co culture systems (Bavister, 1995); not even has the utility of the co culture itself compared to that of a chemically defined medium been proven (Bavister; Tucker et al., 1996). Even with the most extended co culture system, i.e. Vero cells, results in randomized studies are discrepant (Sakkas et al., 1995). Moreover, endometrial thickness of donor patient is in correlation with the rate of positive result of IVF. In other words, if the endometrium be in the secretory phase, the implantation of transplanted embryo is higher than that for proliferative phases (Al-Ghamdi et al., 2008; Richter et al., 2007).

The better results of IVF achieved in secretory phase endometrium, attracted many researchers to add hormones of this phase to the media of co-culture system. The results of these studies did not show improvement in the rate of the implantation and delivery. But, neither the studies which used co-culture alone nor the ones added the hormones secreted during Secretory phase endometrium distinguished the phase of endometrium used by. The aim of this study is to determine if there is any effect of endometrial phase on the development of the embryos that are co cultured with endometrial stromal cells.

\footnotetext{
*Maternity Research Center, Obstetrics and Gynecology Department, Kermanshah University of Medical Sciences, Kermanshah, Iran.

**Fertility and Infertility Research Center, Kermanshah University of Medical Sciences, Kermanshah, Iran.

***Obstetrics and Gynecology Department, Kermanshah University of Medical Sciences, Kermanshah, Iran.

****Maternity Research Center, Neurosurgery Department, Kermanshah University of Medical Sciences, Kermanshah, Iran.
} 


\section{MATERIAL AND METHOD}

This study was carried out in Fertility and infertility research center, Kermanshah University of Medical Sciences. The study was approved by the Ethics Committee of Kermanshah University of Medical Sciences.

Endometrial biopsies were obtained from reproductive fertile women $(20-37 \mathrm{yr})$. With normal menstrual cycles who were undergone bilateral tubal legation or Anterior - posterior colporrhaphy with informed consent forms. The sample collection was done following filling the acceptance form approved by research council of Kermanshah University of Medical Sciences, Iran. According the menstrual phase, the samples divided into two proliferative or Secretory.

Endometrial tissues were collected separately by the groups in $50 \mathrm{ml}$ conical tubes containing phosphate buffered saline (PBS), supplemented with $100 \mathrm{IU}$ penicillin and 100 $\mathrm{mg} / \mathrm{ml}$ streptomycin, and then cooled on crushed ice in a thermos flask and immediately transported to the laboratory.

Endometrial culture. Endometrial samples were minced into small pieces of less than $1 \mathrm{~mm}$ and subjected to mild collagenase digestion. Endometrial stromal cells were isolated as previously described. The stromal cells were cultured and grown to confluence in steroid-depleted medium; DMEM/ F12 and 25\% MCDB-105 (Sigma Chemical Co.) containing antibiotics, supplemented with $10 \% \mathrm{FBS}$ and $5 \mathrm{mg} / \mathrm{mL}$ insulin (Sigma Chemical Co.). The homogeneity of cultures was determined by morphological characteristics.

Mouse embryo assay. Two-cell embryos were flushed from the oviducts on day 2 of pregnancy from 8-week-old Balb/c mice. Following intraperitoneal injection of PMSG (7.5 unit) that followed by 5 unit injection of HMG ( $48 \mathrm{hr}$ later) the embryos were collected from super ovulated mice. The appearance of vaginal plaque demonstrated the zero day of pregnancy. The embryos co-cultured with the same medium (DMEM/F12, 10\% FBS, $5 \mathrm{mg} / \mathrm{mL}$ insulin) in the presence of endometrial stromal cells obtained from either secretory or proliferative phase. Cultured embryos were observed every $72 \mathrm{hr}$ by invert microscope. The progress in the growth and develop of the embryos evaluated during 4-8 cell and blastocyst stages.

Data analysis. The microscpic data of co cultured embryos of two experimental groups were evaluated by using Spss software for windows (Version 16). This data included, the number of morula and Blastocysts that evaluated with T- Test analysis where the quality of zona pelucida and the ratio of granulation with $\mathrm{c} 2(\mathrm{P}<0.05)$.

\section{RESULTS}

Two hundred mouse embryos that cocultured in two conditions; with endometrial stromal cells in proliferative and secretory phases were monitored microscopically during cultivation period (Fig. 1). The data showed there were not significant differences in the distribution of embryos reaching to 2- cells, 4- cells, morula or blastocysts of two groups (Fig. 2).

The quality of embryos in morula stage was evaluated according to the degree of fragmentation and granulation, appearance of zona pelucida and blastomers in four classifications. The data showed, although the percent of morulas in stage B ( $<25 \%$ fragmentation) was higher for secretory group but it was lower in stage A (without fragmentation) in compared with proliferative group. For other two low quality stages, the percent of morulas in stage D ( $>50 \%$ fragmentation) and stage C (25-50\% fragmentation) did not showed significant differences (Fig. 3 ). Thus, the phase that the endometrial stromal cells were in thereby did not affect the quality of embryos.

\section{DISCUSSION}

The present study showed that not only the number of two-cell mouse embryos reaching four-cell morula in two different co-culture media (consisting proliferative and secretory stromal cells) but also the quality of blastomers in morula stage did not differ statistically in two different co-culture groups. However, minor differences only seen in 4 quality of staged embryos. Data from a number of studies provide convincing evidence of a chemical dialogue between the developing embryo and the maternal endometrium (Edwards, 1995). This embryonic- endometrial cross-talk may be beneficial not only to improve the blastocyst rate, but most importantly for the activation of specific paracrine molecules in a timely manner that may improve the chances of implantation of the embryo (Tazuke \& Giudice, 1996). Recently, it has demonstrated that a co-culture system with human endometrial epithelial cells (EEC) is beneficial to the human blastocyst because of the induction of secretion of embryonic paracrine molecules, absorption of toxic material and altering in metabolism involving in the media (De los Santos et al., 1995). Moreover, exogenous treatment of endometrial cells with progesterone or progesterone plus estradiol did not improve the development embryo in a coculture system (Goff \& Smith, 1998).

In conclusion, the data of this study indicated that the endogenous steroids from secretory endometrial stromal cells did not affect on the development embryo as a paracrine process. 

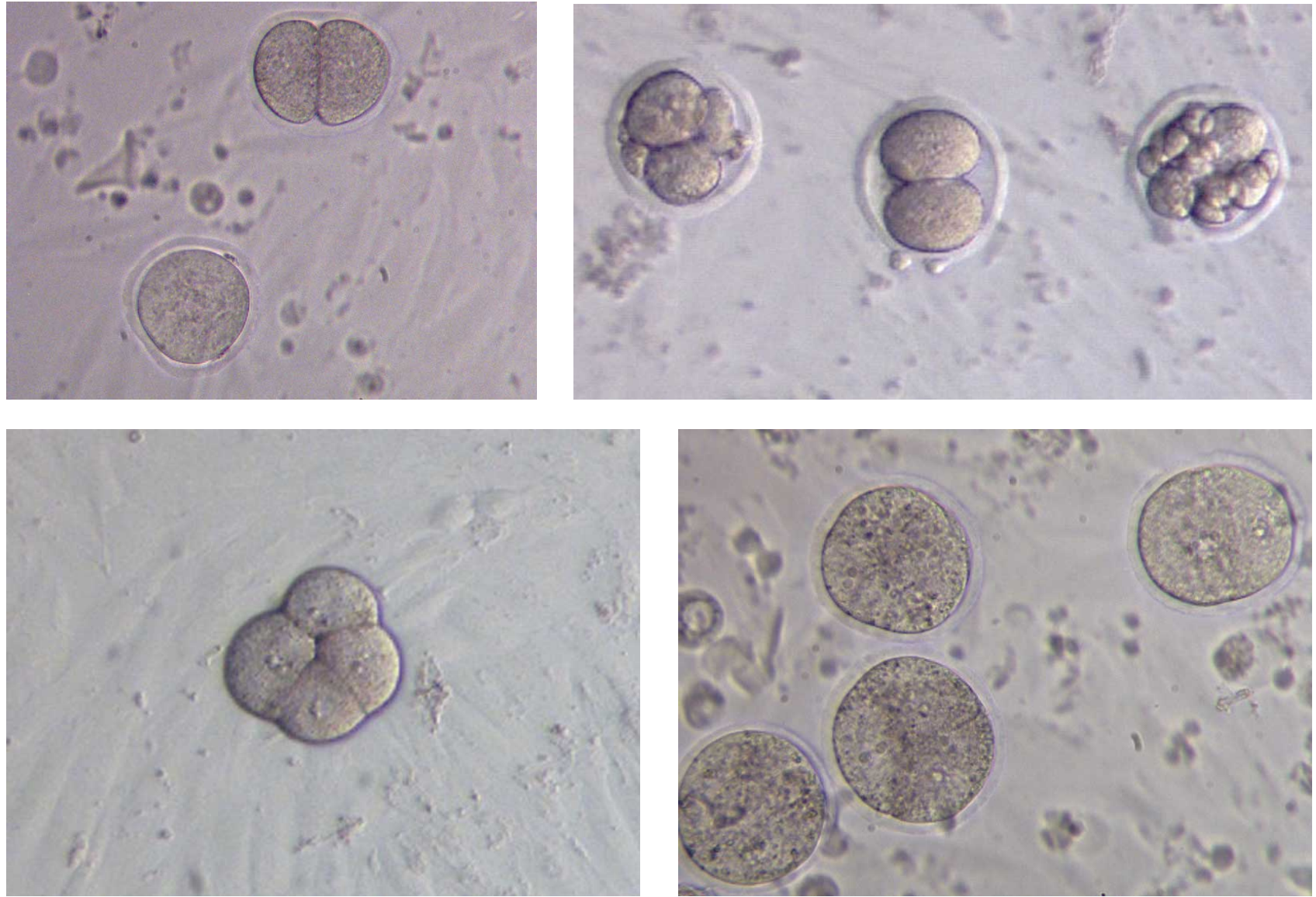

Fig. 1. Developmental stages of mouse embryos observed under light microscope. A. Unfertilized oocyte and two staged embryo on proliferative staged endometrial stromal cells (40X), B. Unfertilized oocyte and two staged embryo on secretory staged endometrial stromal cells (40X), C. Four staged embryo on prolifrative staged endometrial stromal cells; initiation of compaction (10 X), D. Four staged embryo on secretory staged endometrial stromal cells; compaction (40X).
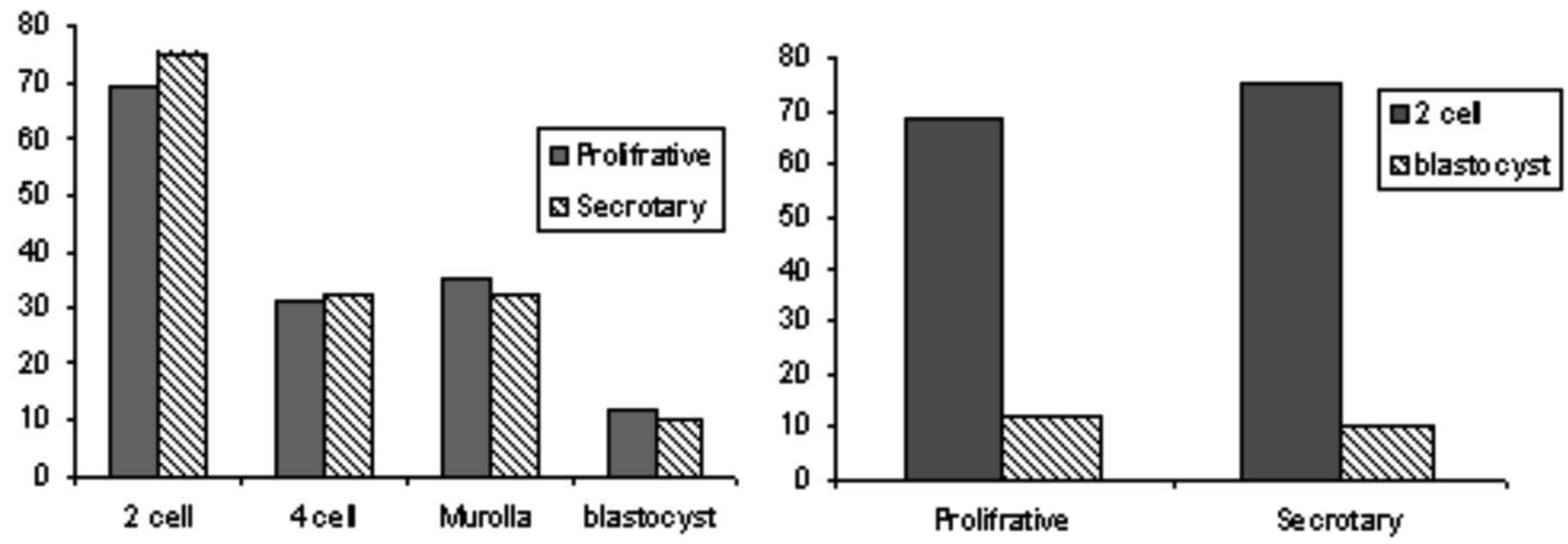

Fig. 2. A. The distribution of staged mouse embryos ( 2 cells, 4 cells, morula and blastocyst). B. Comparison the distribution of blastocysts and 2 cells mouse embryos in two co-culture feeder systems of this study. 


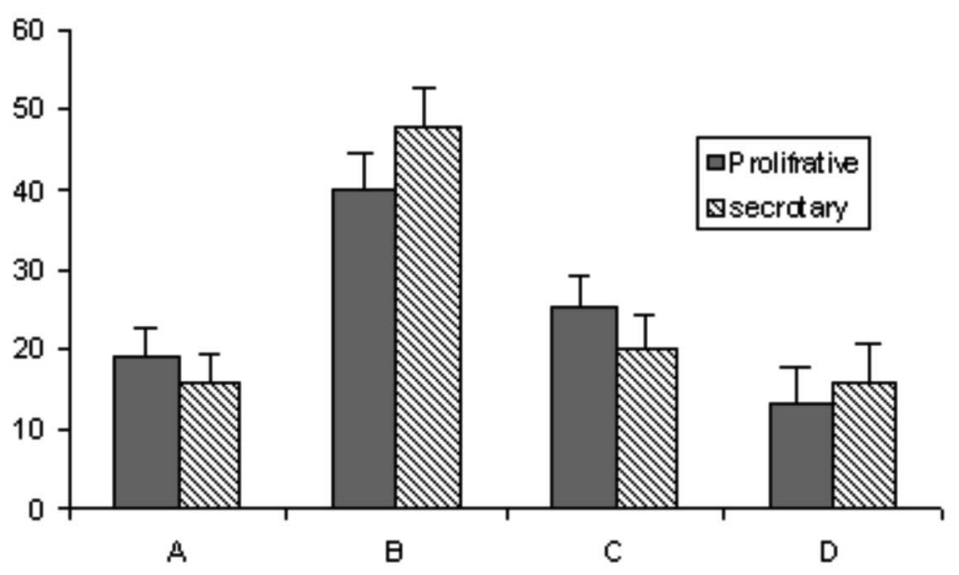

Fig. 3. The distribution of mouse embryos in 4 staged qualities according two cocultue system of this study. A. Without fragmentation. B. $25 \%$ fragmentation. C. $25-50 \%$ fragmentation, D. $>50 \%$ fragmentation $(* \mathrm{P}<0.05)$.

\section{ACKNOWLEDGEMENTS}

The authors would like to express their deep gratitude to the Office of the Vice Chancellor for research of Kermanshah University of Medical Sciences and staff of Fertility and infertility research center for helpful assistance. This research was supported by a research grant (no U-477) from Kermanshah University of Medical Sciences.

FAKHERI, T.; NANKALI, A.; KHAZAEI, M.; GHANBARI, A.; ABEDINI, M. \& SAEIDIBOROJENI, H. Co-cultura de dos células embrionarias de ratón sobre células estromales endometriales humanos en fases proliferativa y secretora. Int. J. Morphol., 30(4):1338-1342, 2012.

RESUMEN: No hubo diferencias significativas en la distribución de los embriones en los cultivos que llegan a las 2 y 4 células, mórula o blastocistos sobre las células del estroma endometrial (fases proliferativa y secretora). El porcentaje de mórulas en etapa A (sin fragmentación), etapa B (<25\% fragmentación), etapa C (25-50\% de fragmentación) y etapa D (>50\% fragmentación), y no mostraron diferencias significativas entre los dos grupos de co-cultivo. Así, la fase en la que se encontraban las células estromales endometriales no afectaron la calidad de los embriones.

PALABRAS CLAVE: Co-cultivo; Embrión; Endometrio; Ratones; Fase proliferativa; Fase secretora.

\section{REFERENCES}

Al-Ghamdi, A.; Coskun, S.; Al-Hassan, S.; Al-Rejjal, R. \& Awartani, K. The correlation between endometrial thickness and outcome of in vitro fertilization and embryo transfer (IVFET) outcome. Reprod. Biol. Endocrinol., 6:37, 2008.

Bavister, B. D. Culture of preimplantation embryos: facts and artifacts. Hum. Reprod. Update, 1(2):91-148, 1995.

Ben-Chetrit, A.; Jurisicova, A. \& Casper, R. F. Coculture with ovarian cancer cell enhances human blastocyst formation in vitro. Fertil. Steril., 65(3):664-6, 1996.

Beydoun, H. A.; Sicignano, N.; Beydoun, M. A.; Matson, D. O.; Bocca, S.; Stadtmauer, L. \& Oehninger, S. A cross-sectional evaluation of the first cohort of young adults conceived by in vitro fertilization in the United States. Fertil Steril., 94(6):2043-9, 2010.

Bongso, A.; Fong, C. Y.; Ng, S. C. \& Ratnam, S. Human embryonic behavior in a sequencial human oviduct-endometrial coculture system. Fertil. Steril., 61(5):976-8, 1994.
De los Santos, M. J.; Mercader, A.; Francés, A.; Portolés, E.; Remohí, J.; Pellicer, A. \& Simón, C. Role of endometrial factors in regulating secretion of components of the immunoreactive human embryonic interleukin-1 system during embryonic development. Biol. Reprod., 54(3):563-74, 1996.

Edwards, R. G. Physiological and molecular aspects of human implantation. Hum. Reprod., 10(Suppl 2):1-13, 1995.

Freeman, M. R.; Witworth, C. M. \& Hill, G. A. Granulosa cell coculture enhances human embryo development and pregnancy rate following in vitro fertilization. Hum. Reprod., 10(2):408$14,1995$.

Goff, A. K. \& Smith, L. C. Effect of steroid treatment of endometrial cells on blastocyst development during co-culture. Theriogenology, 49(5):1021-30, 1998.

Jayot, S.; Parneix, I.; Verdaguer, S.; Discamps, G.; Audebert, A. \& Emperaire, J.C. Co-culture of embryos on homologous endometrial cells in patients with repeated failures of implantation. Fertil. Steril., 63(1):109-14, 1995. 
FAKHERI, T.; NANKALI, A.; KHAZAEI, M.; GHANBARI, A.; ABEDINI, M. \& SAEIDIBOROJENI, H. Co-culture of mouse two-cell embryos on human endometrial stromal cells in proliferative and Secretory phases. Int. J. Morphol., 30(4):1338-1342, 2012.

Menezo, Y. J.; Guerin, J. F. \& Czyba, J. C. Improvement of human early embryo development in vitro by coculture on monolayers of Vero cells. Biol. Reprod., 42(2):301-6, 1990.

Richter, K. S.; Bugge, K. R.; Bromer, J. G. \& Levy, M. J. Relationship between endometrial thickness and embryo implantation, based on 1,294 cycles of in vitro fertilization with transfer of two blastocyst-stage embryos. Fertil. Steril., 87(1):53-9, 2007.

Sakkas, D.; Jaquenoud, N.; Leppens, G. \& Campana, A. Comparison of results after in vitro fertilized human embryos are cultures in routine medium and co-culture on Vero cells: a randomized study. Fertil. Steril., 61(3):521-5, 1994.

Saito, H.; Hirayama, T.; Koike, K.; Saito, T.; Nohara, M. \& Hiroi, M. Cumulus mass maintains embryo quality. Fertil. Steril., 62(3):555-8, 1994.

Schillaci, R.; Ciriminna, R. \& Cefali, E. Vero cell effect on in vitro human blastocyst development: preliminary results. Hum. Reprod., 9(6):1131-5, 1994.

Tazuke, S. I. \& Giudice, L. Growth factors and cytokines in endometrium, embryonic development, and maternal embryonic interactions. Semin. Reprod. Endocrinol., 14(3):231-45, 1996.

Teklenburg, G. \& Macklon, N. S. Review: in vitro models for the study of early human embryo-endometrium interactions. Reprod. Sci., 16(9):811-8, 2009.

Tucker, M. J.; Morton, P. C.; Wright, G.; Ingargiola, P. E.; Sweitzer, C. L.; Elsner, C. W.; Mitchell-Leef, D. E. \& Massey, J. B. Enhancement of outcome from intracytoplasmic sperm injection: does co-culture or assisted hatching improve implantation rates? Hum. Reprod., 11(11):2434-7, 1996.

Wiemer, K. E.; Hoffman, D. I.; Maxson, W. S.; Eager, S.; Muhlberger, B.; Fiore, I. \& Cuervo, M. Embryonic morphology and rate of implantation of human embryos following coculture on bovine oviductal epithelial cells. Hum. Reprod., 8(1):97-101, 1993.

Yeung, W. S.; Ho, P. C.; Lau, E.Y. \& Chan, S. T. Improved development of human embryos in vitro by a human oviductal cell co-culture system. Hum. Reprod., 7(8):1144-9, 1992.
Correspondence to:

Ali Ghanbari, Ph.D.

Fertility and Infertility Research Center

Kermanshah University of Medical Sciences

Kermanshah, P.O. Box 1568.

IRAN

Tel: +98-831-4274617

Fax: +98-831-4281563

Email: aghanbari@kums.ac.ir

Received: 01-03-2012

Accepted: 08-05-2012 